\title{
The International Association of Hydrogeologists
}

\author{
http://www.iah.org
}

\begin{abstract}
Aim
The International Association of Hydrogeologists exists to provide a forum for professionals working in the field of groundwater to exchange ideas, information and experiences. In addition to serving its members, it promotes a wider understanding of groundwater issues through public information, education and research on groundwater and its sustainable development, management and protection. These issues are not always well understood by the general public, policy makers, and even some professionals in other disciplines. It is the aim of IAH to provide a voice for groundwater in world water policy issues, to champion its proper use and support research and information on groundwater throughout the world.
\end{abstract}

\section{History}

The origins of the Association were modest. Informal discussions at the International Geological Congress in Algiers in 1952 identified a common interest among geologists working on groundwater in forming a society of fellow specialists to maintain professional contacts between IGC meetings. A working group was set up which led to the International Association of Hydrogeologists being formally established in 1956 at the IGC in Mexico City and subsequently (1964) recognised as an affiliated body of the IUGS. Prof Fourmarier (Switzerland) was elected as the first President, Louis Dubertret (France) as the first Secretary and Gilbert Castany (France) as the first Treasurer. From these small foundations IAH has grown from a few tens of members meeting every four years at ICGs to a membership of over 3,500 members in 135 countries holding or co-sponsoring many meetings around the world each year.

IAH held its first Congress in Paris in 1957. We held our 32nd Congress in Mar del Plata, Argentina in October 2002 and are beginning to plan our 34th and 50th anniversary Congress in France in 2006 in recognition of the fact the majority of the founding fathers of the Association were from France. For its first 44 years IAH was run as an unincorporated body with no formal corporate status but the increasing scale and complexity of its affairs led the governing council in 1997 to commence plans to give IAH corporate status. In 2000 IAH was incorporated as a non-profit organisation with charitable status, registered in the United Kingdom. At the Cape Town Congress of IAH in November 2000 the membership formally approved the transfer to the incorporated body. This came into effect on $1 \mathrm{st}$ January 2001.

\section{Organisational structure and officers}

The Association is managed by its Council, who are also the trustees of the Charity. The Council consists of a President, Secretary-General, Treasurer, Vice-Presidents representing each of eight world regions, the immediate Past President and a Scien- tific Programme Member. The members of the IAH Council come from academic, public service (geological survey and environmental regulation) and consultancy backgrounds and this distribution reflects the diversity of the membership as a whole.

The current president of IAH is

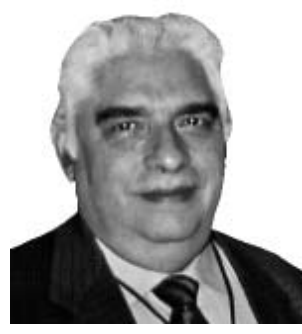
Professor Emilio Custodio of Spain. He is a professor of Civil Engineering at the Technical University of Catalonia in Barcelona, and is currently Director General of the Geological and Mining Institute of Spain (IGME). He has been President since 2000 and serves for four years.

The current Secretary General is Dr Andrew Skinner of the United Kingdom. He has been Secretary-General since 1989, and is one of only four persons who have held this post in the life of IAH. The others are Louis Dubertret, Gilbert Castany and Erik Romijn (The Netherlands). Andrew Skinner is Head of Environmental Quality for the Environment Agency of England and Wales.

Treasurer since 1994 is Willi Struckmeier (Germany), Head of Groundwater at the Federal Institute for Geosciences (BGR), Hannover. He also leads the IAH Commission on Hydrogeological Maps, which is linked to the Commission for the Geological Map of the World.

The immediate Past President is Professor Michael Knight (Australia), Head of the Centre for Groundwater Management at the University of Technology, Sydney. During his term as President (1996-2000) he was responsible for leading the change of corporate structure of IAH.

The International Office of IAH, situated in the United Kingdom, manages membership and coordinates publications. IAH has a number of membership classes and has a tiered membership fee structure, which means that persons living in lower income countries pay a lesser fee. Student members are welcomed and also pay a lower rate. IAH sets it membership fees according to the principle that students and members in lowincome countries pay only for the products they receive and the administration of the Association and the funding of our outreach programmes comes from the higher membership fees paid by members in more prosperous countries.

Where groundwater specialists in low-income countries do not have the personal resources to join IAH, they can often take advantage of the sponsored membership scheme funded by donations from existing members. IAH also has a corporate membership scheme, which allows companies to support IAH and to enrol their staff in the Association.

A key strength of IAH is its National Chapters where members in a particular country group together to organise national 
activities and promote the aims of IAH in their country. These Chapters operate under their own constitutions and elect national officers to administer the affairs of IAH locally. There are over 25 national chapters and many also undertake the local administration of IAH, recruiting members and collecting fees.

The membership of IAH is diverse and, although the majority of its members have a background in earth sciences, we enjoy the support of a wide range of other disciplines interested in groundwater. It is for this reason that the Association has adopted the informal subtitle of "the international groundwater organisation". In addition to our affiliation to IUGS and partnership with sister societies affiliated to IUGS, we also work with many water related NGOs and with bodies in the UN system concerned with water affairs, especially UNESCO, FAO, IAEA and WMO. IAH is also a member of the World Water Council.

\section{Scientific activities}

Early in the life of IAH, specialist Commissions were established as the main method for taking forward work on particular topics including holding specialist meetings and producing memoirs and reports. Over time the number and scope of Commissions has changed although three of the early Commissions, Karst (founder chairman André Burger), Hydrogeological Maps (founder chairman Herbert Karrenberg) and Mineral and Thermal Waters (founder chairman Karl Fricke) are still very active. In addition to these three, there are currently active Commissions on: Education and Training, Groundwater in Urban Areas, Groundwater Protection, Hardrock Hydrogeology, Management of Aquifer Recharge, and Transboundary Aquifer Resource Management. Commissions are in the process of formation on Groundwater Dependent Ecosystems and Management of Groundwater in Coastal Areas. The successful management of groundwater and its proper integration into the management of the world water resources demands that the scientific outputs of these Commissions are effectively integrated and promoted, and IAH is now drawing together a group of senior members and supporters to realise this goal. This was one of the outputs of a special meeting of Council on the future strategy for IAH held in Stâna de Vale, Romania in May 2002, and adopted by the IAH Council meeting in Mar del Plata, Argentina in October 2002.

\section{Publications}

The initial publication series for IAH was the memoirs of the regular congresses. A book series, International Contributions to Hydrogeology, was established in 1984, which still continues. It is now published by the Balkema Company of the Netherlands. Volume 23 in the series was published in 2002.

In $1990 \mathrm{IAH}$, on the initiative of Gene Simpson, began its own journal, now called Hydrogeology Journal. Each annual volume is made up of six issues and is sent by mail direct to all members. Each volume contains 650-700 pages of peerreviewed papers on hydrogeology and related topics, including as the first issue of the year, a theme issue on a special topic. Hydrogeology Journal is a listed publication in the Science Citation Index. In addition to the hard copy publication, Hydrogeology Journal is also available free to members on line. The current Executive Editor of the journal is Cliff Voss. The IAH Journal is published by Springer of Germany.

We publish a hard copy newsletter (News and Information) every 4 months and an electronic newsletter, Groundwater eNews, every two months. The IAH web site has been well established for several years and recently IAH has expanded a number of its web services for members to include the on-line payment of fees, on line membership sign-up and membership directory.

\section{Perspectives}

IAH is one of the most active of the IUGS affiliate organisations. It has more than doubled its membership in the last 15 years from 1,700 members in 1987 to 3,600 at the end of 2002. This growth has reflected the growth in interest in groundwater as an academic discipline, as a key issue in the management of the environment and the alleviation of poverty. Although membership growth has slackened in the last few years, in contrast to many membership based scientific and technical organisations, IAH has continued to prosper. The majority of IAH funds come from membership fees so a continued strong membership, especially in developed countries, is necessary for us to meet our goals.

A major target for IAH in 2003 is the World Water Forum to be held in Japan in March. Working in partnership with the World Bank, UNESCO, FAO and IAEA, IAH has been successful for the first time in getting groundwater recognised as a major conference theme in a World Water Meeting, and we hope to influence the decisions and programmes which flow from this conference to progress scientifically sound management of the world's groundwater resources. At out Congress in Argentina in October, we launched the prototype of the first groundwater map of the world and this is one of the products that IAH will be taking to Japan.

\author{
Dr. Andrew Skinner \\ IAH Secretariat \\ P.O. Box 9 \\ Kenilworth, CV8 1JG, \\ $U K$ \\ E-mail:iah@iah.org
}

